Investigations

\title{
Effect of Chelating Compounds of Microelements for Iodine Enrichment of Cow Milk
}

\author{
${ }^{1}$ Elena Vladimirovna Bykova, ${ }^{2}$ Sergey Petrovich Voronin, ${ }^{1}$ Aleksandr Petrovich Korobov, \\ ${ }^{1}$ Alexey Alekseevich Vasiliev, ${ }^{2}$ Anatoliy Petrovich Gumeniuk, \\ ${ }^{1}$ Alexandr Valentinovich Kudinov and ${ }^{1}$ Yuliya Nikolaevna Zimens \\ ${ }^{1}$ The Saratov State Agrarian University named after N.I. Vavilov, 1, \\ Teatralnaya Sq., Saratov, 410012, Russian Federation, Russia \\ ${ }^{2}$ Joint Stock Company "Bioamid”, 27, Mezhdunarodnaya Str., Saratov, 410033, Russia
}

\section{Article history}

Received: 04-12-2017

Revised: 14-03-2018

Accepted: 12-04-2018

\section{Corresponding Author:}

Elena Vladimirovna Bykova

The Saratov State Agrarian

University named after N.I.

Vavilov, 1, Teatralnaya Sq.,

Saratov, 410012, Russian

Federation, Russia

Email: elena-v-bykova@yandex.ru

\begin{abstract}
This article discusses the problem of iodine deficiency and proposes a solution to this problem by enriching milk with iodine due to the use of organic compounds of microelements in diets of cows. The article presents the results of comparative study of inorganic and organic micromineral additives' influence on the content of iodine in milk and activity of thyroid hormones in the blood of cows. It has been established that the replacement of inorganic iodine (KI) with organic compound (OMEK-J, chemically iodized baker's yeast) increases iodine content in milk in 3-5 times. Similar effect has been observed for combination of inorganic and organic sources of iodine in 5:1 ratio with organic compounds of trace elements - metals (OMEK-Met, where Met-Fe, Co, $\mathrm{Mn}, \mathrm{Zn}, \mathrm{Cu}$ ) being chelates with L-aspartic acid. Analysis of hormonal screening of the experimental cows' blood showed the positive correlation between the content of thyroid hormones - triiodothyronine and thyroxine in the blood and the content of iodine in the milk.
\end{abstract}

Keywords: Microelements, Iodine, Milk, Hormones, Cows

\section{Introduction}

Iodine is an essential element in the nutrition of mammals required for the synthesis of thyroid hormones - thyroxin $\mathrm{T} 4$ and its active form triiodothyronine T3. Thyroid hormones regulate growth and development of the organism, metabolism of glucose, protein, fat and reproductive functions.

Currently, the struggle against iodine deficiency is coordinated on a global scale by the International Council for Control of Iodine Deficiency Disorders. To combat the iodine deficiency, it is recommended to use iodized salt, iodized vegetable oil, bread, products of animal and fish farms (Antonova, 2004; Fisinin, 2010; Korobov et al., 2016; Poddubnaya et al., 2016; Zamarin, 1965; Zimens et al., 2017).

Considerable efforts of the international community have resulted in significant progress in combating iodine deficiency: the community managed to eliminate the risk of deviations in brain development in millions of infants and to significantly reduce the consequences of iodine deficiency in Europe, Asia, Africa and America.
In 95 countries, including China, overall salt iodization is used. In India, sales of uniodized salt is prohibited. In industrialized countries experiencing natural iodine deficiency (the USA, Canada, Switzerland, the UK, Scandinavian countries, Australia), implementation of iodine prophylactic programs resulted in elimination of iodine-deficiency diseases (Fisinin, 2010).

The Middle Volga and Saratov regions are deficient regions for iodine content in soil and water (Antonova, 2004). The basic research of Zamarin (1965; Korobov et al., 2016) about the influence of iodine deficiency on the physiological state of dairy cows, the level of milk production, iodine content in milk of cows in the Saratov Right Bank of the Volga River allowed him drawing conclusions about the low iodine content in the milk from cows, which was associated with insufficient function of the thyroid gland in areas with iodine deficiency in the environment. The content of iodine in milk from 208 cows collected in 37 settlements in 6 districts of the Saratov region in the summer grazing period was $19.3 \pm 4.6 \mu \mathrm{g} / \mathrm{l}$ (Korobov et al.,
(C) 2018 Elena Vladimirovna Bykova, Sergey Petrovich Voronin, Aleksandr Petrovich Korobov, Alexey Alekseevich Vasiliev, Anatoliy Petrovich Gumeniuk, Alexandr Valentinovich Kudinov and Yuliya Nikolaevna Zimens. This open access article is distributed under a Creative Commons Attribution (CC-BY) 3.0 license. 
2016). According to Zamarin (1965), determination of iodine concentration in milk may be used for establishing the boundaries of the endemic foci of iodine deficiency in humans and animals. The products of animal origin are an important source of iodine in food. In Germany, milk and milk products provide on the average $37 \%$ of iodine that enters the organism of people in this country. In Denmark, over $44 \%$ of iodine comes with milk. In the USA, the main source of iodine in food is milk. Therefore, milk, purposefully enriched with iodine, can serve as one of the main sources of iodine intake into the human body.

Lack of minerals in the diet of animals is traditionally compensated by introducing them into fodder in inorganic form as components of sulfates, carbonates, chlorides, etc. In recent years, specialists in feeding animal around the world have shown their interest in using organic compounds of microelements (Pasmussen et al., 2002).

Russian company JSC "Bioamid", Saratov, has first developed a new organic mineral complex of iodine OMEK-J and a complete lineup of organic complexes of essential metal microelements based on L-aspartic acid OMEK-Met ( $\mathrm{Met}-\mathrm{Fe}, \mathrm{Co}, \mathrm{Cu}, \mathrm{Zn}, \mathrm{Mn}$ ). Iodine in the organic complex is represented by covalent bond with the protein biomass of bakery yeast. In this form, it is resistant to external factors and accordingly is not lost during the production and storage of fodder, which is typical for inorganic iodine compounds. In this form, iodine cannot participate in side reactions with components of the fodder. The complex of useful properties allows using reduced amounts of iodine in the formulations of animal fodder.

The goal of this research was the comparative study of increasing in iodine content in milk and the activity of thyroid hormones in the blood of cows in the summer pasture period by inorganic and organic micromineral fertilizing.

\section{Materials and Methods}

Two experiments on the use of chelating compounds of trace elements for the iodine enrichment of cow milk were performed.

The experiments were carried out on the KFK Bykova O.M. dairy farm in the summer pasture period of 2015-2016 years on three groups of cows with 10 heads in each, picked by the principle of analogs with regard to the breed, age, lactation, date of last calving and the level of milk producing ability. There are schemes of scientific and economic experiments in Table 1.

The norms of feeding dairy cows with live weight of $500 \mathrm{~kg}$ and the milk yield of $20 \mathrm{~kg}$ per day (Norms and rations of feeding agricultural animals, 1985) envisage feeding them 14.6 FU (fodder units), $168 \mathrm{MJ}$ of total energy, $17.2 \mathrm{~kg}$ of dry matter, 2,245.0 $\mathrm{g}$ of raw protein, $4,130.0 \mathrm{~g}$ of fiber, sugar $1,315.0$ and $11.7 \mathrm{mg}$ of iodine. On the main diet, each animal in the experimental groups received $55.0 \mathrm{~kg}$ of Sudan grass, $3.5 \mathrm{~kg}$ of Sudan grass hay, $2.0 \mathrm{~kg}$ of barley, $1.0 \mathrm{~kg}$ of rye grain, $0.1 \mathrm{~kg}$ of table salt and premix. The main diet in experimental period was sufficient in energy content, main groups of nutrients, but insufficient in some macro- and micronutrients. In particular, iodine deficiency per 1 head was $10.9 \mathrm{mg}$. To compensate the iodine deficiency and other trace elements, animals received them additionally, as indicated below.

\section{1st Experiment}

The control group received only the main diet consisting of green Sudan grass, Sudanese hay, barley and rye grain. The first test group received basic daily diet and $11 \mathrm{mg}$ of iodine in the form of KI, the second test group in addition to the main diet received $11 \mathrm{mg}$ iodine in the form of OMEK-J.

Table 1: Experiment scheme

\begin{tabular}{|c|c|c|}
\hline \multirow[b]{2}{*}{ Group } & \multicolumn{2}{|l|}{ Feeding conditions } \\
\hline & Preliminary period & Accounting period \\
\hline \multicolumn{3}{|c|}{ First experiment scheme } \\
\hline Reference & MD (main diet) & MD (main diet) \\
\hline 1 - experimental & MD & $\mathrm{MD}+11.0 \mathrm{mg}$ of $\mathrm{I}$ in the form $\mathrm{KI}$ \\
\hline 2 - experimental & MD & $\mathrm{MD}+11.0 \mathrm{mg}$ of $\mathrm{I}$ in the form of OMEK-J \\
\hline \multicolumn{3}{|c|}{ Second experiment scheme } \\
\hline Reference & MD & $\begin{array}{l}\text { MD + Organic of microelements (OMEK-Met) } \\
+2.0 \mathrm{mg} \text { of I in the form of OMEK-J }\end{array}$ \\
\hline 1 - experimental & MD & $\begin{array}{l}\mathrm{MD}+\text { Sulfates of microelements } \\
+10.0 \mathrm{mg} \text { of } \mathrm{I} \text { in the form KI}\end{array}$ \\
\hline 2 - experimental & $\mathrm{MD}$ & $\begin{array}{l}\text { MD }+ \text { Organic of microelements (OMEK-Met) } \\
+10.0 \mathrm{mg} \text { of } \mathrm{I} \text { in the form KI } \\
+2.0 \mathrm{mg} \text { of } \mathrm{I} \text { in the form of OMEK-J }\end{array}$ \\
\hline
\end{tabular}




\section{2nd Experiment}

The animals of the control group received in additionn to the main diet $100 \mathrm{~g}$ of the premix with trace minerals - metals in the organic form of OMEK-Met 10 times lower in concentration than in the first test group and $2.0 \mathrm{mg}$ of $\mathrm{I}$ in the form of OMEK-J. The animals of the first test group received in addition to the main diet $100 \mathrm{~g}$ of the premix with the following composition per 1 ton in the form of sulfates: $\mathrm{Mn}-1950 \mathrm{~g}, \mathrm{Zn}-6910 \mathrm{~g}$, $\mathrm{Cu}-960 \mathrm{~g}, \mathrm{Co}-100 \mathrm{~g}$, $\mathrm{Se}-20 \mathrm{~g}$ in the form of sodium selenite and $10.0 \mathrm{mg} I$ in the form of KI. The animals of the second experimental group, received in addition to $100 \mathrm{~g}$ of premix, of the same composition as for the control group, $10.0 \mathrm{mg}$ of $\mathrm{I}$ in the form $\mathrm{KI}$ and $2.0 \mathrm{mg}$ of $\mathrm{I}$ in the form of OMEK-J.

The conditions of feeding and keeping animals were the same except for the factors studied. The account of milk productivity was performed every ten days by results of control milking 2 or 3 times a day (Spiridonov and Murashova, 2010). The duration of the experiments was 122 days, of which the preliminary period of the experiment was 30 days, the accounting period was 92 days.

\section{Results}

During the scientific and economic experiment at the chemical laboratory of JSC "Bioamid", iodine content in milk samples of animals in the reference and test groups was determined at the beginning, at the first decade and at the end of the accounting period (Table 2). The quantitative analysis was carried out by the generally accepted kinetic thiocyanate-nitrite method.

Analysis of the results in Table 2 showed that iodine content in milk increased up to $60.0 \mu \mathrm{g} / \mathrm{l}$ almost immediately after the start of feeding dairy cows with iodine supplement in the form of organic compound OMEK $-\mathrm{J}$ and by the end of the experiment it increased up to $85 \mu \mathrm{g} / \mathrm{l}$. Iodine content in the milk of the reference group and the 1st experimental group of cows who received iodine with food in inorganic form of KI did not exceed $30.7 \mu \mathrm{g} / \mathrm{l}$.

The results of the second experiment shown in Table 2 for the second experimental group confirmed the stimulatory role of OMEK-J for increasing the iodine content in milk. This effect was manifested even when the content of organic iodine in the premix was $20.0 \mathrm{~g} / \mathrm{t}$, but against the background of $100.0 \mathrm{~g} / \mathrm{t}$ of inorganic iodine and microelements-metals in the form of OMEK-Met. The results obtained for the control group showed that adding only $20.0 \mathrm{~g} / \mathrm{t}$ of iodine in the form of OMEK-J was not sufficient for obtaining milk with iodine content of more than $25.0 \mu \mathrm{g} / \mathrm{l}$. It can be concluded that it is optimal to mix inorganic iodine (low cost) with OMEK-J organic iodine (high cost) in rations of 5:1 to increase the content of iodine in milk.

To determine the level of thyroid hormones and the thyrotropic hormone of hypophysis, blood was taken twice from the experimental cows at the beginning and at the end of the second experiment. The levels of thyrotropine, T4 free, T4 overall and T3 were determined on a biochemical and immunoenzymometric automated analyzer of type "Chem Well" (Table 3).

Table 2: Iodine content in milk of cows, $\mu \mathrm{g} / \mathrm{l}$

\begin{tabular}{|c|c|c|c|c|}
\hline \multirow[b]{2}{*}{ Group } & & \multicolumn{3}{|c|}{ Accounting period of the experiment } \\
\hline & & Beginning & First decade & End \\
\hline \multicolumn{5}{|l|}{ First research and production experiment } \\
\hline Reference & & $23.1 \pm 2.3$ & $23.5 \pm 2.2$ & $23.2 \pm 2.7$ \\
\hline 1 - experimental & & $23.4 \pm 2.4$ & $25.5 \pm 2.8$ & $30.7 \pm 1.3 *$ \\
\hline 2 - experimental & & $22.3 \pm 2.5$ & $60.2 \pm 4.1 * *$ & $85.0 \pm 5.4 * *$ \\
\hline \multicolumn{5}{|c|}{ Second research and production experiment } \\
\hline Reference & & $19.0 \pm 2.0$ & $20.5 \pm 2.2$ & $25.0 \pm 0.5$ \\
\hline 1 - experimental & & $21.0 \pm 2.3$ & $23.0 \pm 2.4$ & $39.0 \pm 1.7^{*}$ \\
\hline 2 - experimental & & $19.0 \pm 3.4$ & $51.0 \pm 3.1 * *$ & $82.0 \pm 5.2 * *$ \\
\hline \multicolumn{5}{|l|}{ Note: $^{*}-\mathrm{p}<0.95 ; * *-\mathrm{p}>0.99$} \\
\hline \multicolumn{5}{|c|}{ Table 3: Hormonal screening of experimental cows' blood } \\
\hline \multirow[b]{2}{*}{ Indicator } & \multicolumn{4}{|l|}{ Group } \\
\hline & Reference & & 1 - experimental & 2 - experimental \\
\hline \multicolumn{5}{|l|}{ Beginning of the experiment } \\
\hline Thyrotropic hormone TTH, $\mu \mathrm{Un} / \mathrm{ml}$ & $2.1+0.21$ & & $1.6+0.2$ & $2.0+0.3$ \\
\hline Triiodothyronine $\mathrm{T} 3, \mathrm{nmol} / \mathrm{l}$ & $0.8 \overline{3}+0.1$ & & $0.6 \overline{6}+0.2$ & $1.4 \overline{6}+0.1 *$ \\
\hline $\mathrm{T} 4$ free thyroxine, $\mathrm{nmol} / \mathrm{l}$ & $10.6 \pm 0.7$ & & $10.1 \pm 1.9$ & $13.3 \pm 1.4$ \\
\hline T4 total thyroxine $\mathrm{nmol} / \mathrm{l}$ & $30.5 \pm 0.9$ & & $28.9 \pm 4.5$ & $38.2 \pm 2.3$ \\
\hline T4:T3 ratio & $36.7^{-}$ & & $43.8^{-\cdots}$ & $26.2^{-10}$ \\
\hline \multicolumn{5}{|l|}{ End of the experiment } \\
\hline Thyrotropic hormone TTH, $\mu \mathrm{Un} / \mathrm{ml}$ & $2.4+0.3$ & & $2.1+0.2$ & $2.4+0.2$ \\
\hline Triiodothyronine $\mathrm{T} 3, \mathrm{nmol} / \mathrm{l}$ & $1.25+0.2$ & & $1.35+0.2$ & $1.6+0.1$ \\
\hline $\mathrm{T} 4$ free thyroxine, $\mathrm{nmol} / \mathrm{l}$ & $12.8+0.9$ & & $13.1+1.9$ & $12.2+1.43$ \\
\hline T4 total thyroxine nmol/l & $32.3+3.1$ & & $34.7+5.0$ & $37.0+3.3$ \\
\hline $\mathrm{T} 4: \mathrm{T} 3$ ratio & 26.8 & & 25.7 & 23.1 \\
\hline
\end{tabular}


As one can see from the results in Table 3, introduction of iodine into the diet of cows resulted in the significant increase in the concentration of the TTH hormone and the maximum level was observed in the blood of reference and second experimental group cows that received fodder containing iodine in the organic form of OMEK-J. Hence, the increased content of total thyroxine and triiodothyronine in the blood of cows of the second experimental group, as compared with the first group, seems natural.

\section{Discussion}

The hormonal blood screening of the experimental cows confirmed the positive correlation between the T3 and T4 content in the blood with the iodine content in the milk; and the results of the second experiment fitted into this pattern. Studies conducted in Germany also indicated an increase in the concentration of iodine in cow milk, which had been explained by the increased use of iodinated mineral mixture (Antonova, 2004).

Enrichment of the rations of cows with organic iodine compounds not only contributes to the increase in the iodine content in milk, but also to an increase in the fat content in it (Spiridonov and Murashova, 2010), which is related to the action of the thyroid hormone produced by the thyroid gland, the main part of which is iodine.

This method of using iodine in feeding cows can be considered safe, because trace elements are fed as part of the feed mixers and eating them in large quantities is not possible.

Based on the experiments performed in 2015-2016 at two farms in the Saratov region, premixes with organic compounds of microelements were introduced into the practice of feeding dairy cows. After six months of receiving diets with premixes that contained microelements in the form of OMEK-Met, including OMEK-J, iodine content in milk of cows at the breeding farm "Meliorator" in the Marksovsky district of the Saratov region amounted to $130.0 \mu \mathrm{g} / \mathrm{l}$, at LLC "Berezovskoe", in the Engels district of the Saratov region - $110.0 \mu \mathrm{g} / \mathrm{l}$.

In the future these farms will be used for experiments with the use of premixes with a higher level of iodine in the diet, for the purpose of bringing its content per one liter of milk up to $180.0-200.0 \mu \mathrm{g}$, which is optimal to eliminate the iodine deficiency for humans according to the World Health Organization.

\section{Conclusion}

Analyzing the conducted researches, it is possible to draw the following conclusions: Feeding cows with fodders with the addition of organic iodine in the form of OMEK-J stimulates ingress of iodine into the milk. Compared to inorganic form, reaching certain level of iodine content in milk requires 3 to 5 times less organic form. To reduce the cost of feeding, a certain combination of inorganic and organic forms of iodine in feeds should be used. The ratio of 5:1 Is sufficient.

Milk may be a reliable source of iodine for humans. Continuation of the research on the use of OMEK-J in feeding cows is aimed at solving this important problem, which is especially relevant for the residents of the Russian regions with significant natural iodine deficiency.

\section{Acknowledgement}

We thank our University for supporting our research.

\section{Author's Contributions}

All the authors participated in all experiments, coordinated the data-analysis and contributed to the writing of the manuscript.

\section{Ethics}

This article is original and contains unpublished material. The corresponding author confirms that all of the other authors have read and approved the manuscript and there are no ethical issues involved.

\section{References}

Antonova, M.S., 2004. Boryba s iod-defitsitom: Istoriya $\mathrm{i}$ sovremennost. [Combating iodine deficiency: history and modernity]. Electron. J. Res. Russia, 7: 2190-2198.

Fisinin, V.I., 2010. Innovatsionnie puti razvitiya svinovodstva $\mathrm{v}$ Rossii. [Innovative way of pig breeding development in Russia]. Pig Breeding.

Korobov, A.P., A.P. Gumenyuk and E.V. Bykova, 2016. OMEK-J- istochnik ioda dlya korov [OMEK-J is the source of iodine for cows]. Cattle Breed. Russia, 5: 60-61.

Pasmussen, L.B., L. Ovesen, I. Bülow,T. Jorgensen and N. Knudsen et al., 2002. Dietary iodine intake and urinary iodine excretion in a Danish population: Effect of geography, supplements and food choice. Br. J. Nutr., 87: 61-69. DOI: 10.1079/BJN2001474

Poddubnaya, I.V., A.A. Vasiliev, Y.A. Guseva, Y.N. Zimens and M.Y. Kuznetsov, 2016. Comprehensive assessment of the impact of the additive "abiopeptide with iodine" on the growth, development and marketable quality of the lena' sturgeon grown in cages. Biosci. Biotechnol. Res. Asia, 13: 1547-1553. DOI: 10.13005/bbra/2297

Spiridonov, A.A. and E.V. Murashova, 2010. Obogaschenie Iodom Produktsii Zhivotnovodstva. [Enrichment with Iodine in Livestock Production]. In: Norms and Technologies, Spiridonov, A.A. and E.V. Murashova (Eds.), LLC "Beresta" Printing House, Saint Petersburg. 
Zamarin, L.G., 1965. Iodnaya nedostatochnost u krupnogo rogatogo skota v Saratovskom Pravoberezhe. [Iodine deficiency in cattle on the right bank of the Volga River in the Saratov region]. PhD Thesis, Saratov.
Zimens, Y.N., I.V. Poddubnaya, A.A. Vasiliev, Y.A. Guseva and V.V. Kiyashko et al., 2017. Effects of iodized yeast as feed supplement on growth and blood parameters in Lena Sturgeon (Acipencer baerii stenorrhynchus nicolsky) juveniles. Ecol. Environ. Conservat., 23: 603-610. 